\title{
Strategy-Based Reading Instruction Utilizing the CALLA Model in an ESL/EFL Context
}

\author{
Young-Mee Suh
}

\begin{abstract}
This paper describes four English reading instruction approaches which are primarily used in ESL/EFL reading classes: Experience-Text-Relationship, the Reciprocal Teaching Approach, Transactional Strategy Instruction, and the Cognitive Academic Language Learning Approach. Each reading approach is based on reading strategy instruction, and students are considered active learners in these paradigms. The CALLA model in particular puts emphasis on both language and content development while teaching strategies explicitly. Considering that the CALLA model is based on promotion of language and content at the same time, it can be a desirable instructional model in ESL/EFL reading classes. Targeting postsecondary school students whose English reading proficiency levels are in between intermediate and high-intermediate, this paper illustrates each stage of the CALLA instructional model and provides a sample lesson plan. ESL/EFL teachers may utilize the demonstration or the lesson plan in a real teaching situation to help learners be successful ESL/EFL readers while increasing their content knowledge and language proficiency.
\end{abstract}

\section{Introduction}

There has been much research emerging concerning effective ways of teaching English reading comprehension to L1 learners using strategy-based reading instruction (Dole, Duffy, \& Pearson, 1991; Kusiak, 2001). The L1 strategy-based reading studies have shown that students' comprehension abilities improve when they are taught to use comprehension strategies. Recently, to enhance students' comprehension in reading English texts, L1 researchers have focused on implementing multiple strategies in the classroom. They suggested that teachers should teach varied strategies or combinations of them rather than focusing on a given strategy exclusively (Alfassi, 1998; Vaughn \& Klingner 1999).

Interestingly enough, however, there have been relatively few studies on effective reading strategy training for second language students. Research in the field of L2 reading instruction has not addressed strategic engagement with texts, and consequently, many ESL learners struggle with reading, especially in the context of university content courses (Nist \& Diehl, 1990). More studies on strategy-based reading instruction in $\mathrm{L} 2$ contexts need to be done to see whether success in L1 
contexts in terms of strategy-based reading instruction can be replicated in L2 contexts.

In this paper, I will describe the Cognitive Academic Language Learning Approach (CALLA) in Chamot and O'Malley (1997) as a way of teaching strategybased reading to ESL/EFL learners. I will also illustrate how to teach reading to ESL/EFL readers utilizing the CALLA approach. For this purpose, I will first introduce and compare the four main L2 reading approaches; that is, ExperienceText-Relationship (ETR), the Reciprocal Teaching Approach (RTA), Transactional Strategy Instruction (TSI), and the Cognitive Academic Language Learning Approach (CALLA). I will focus on the CALLA method, describing it in detail and offering a lesson plan as an illustration of how this approach can be applied in the classroom. I focus especially on CALLA because students are able to learn how to use strategies to enhance content knowledge, L2 reading, and other skills at the same time. ESL/EFL teachers will be able to utilize this lesson plan in their reading classes to help ESL/EFL learners bolster their reading proficiency at the grade school level.

\section{Literature Review}

As in L1 reading instruction, approaches to ESL reading instruction have shifted from the drill-based practice models to more cognitively based comprehension models. Much research has focused on effective combined reading strategies within the L1 context (Baker, 2002; Brown, 2002; Duke \& Pearson, 2002; Pressley, 2002a, 2002b; Trabasso \& Bouchard, 2002). Trabasso and Bouchard (2002) identified individual reading strategies which have important influences on L1 reading comprehension. Duke and Pearson (2002) reviewed effective instructional strategies in L1 reading comprehension. Baker (2002), Brown (2002), and Pressley (2002a, 2002b) found that instruction of multiple strategy use is more effective than individual strategy instruction.

Compared to L1 reading strategy research, however, there is relatively little L2 research on strategic reading instruction, especially in EFL contexts. More research needs to be done within the field of L2 reading instruction in order "to develop strategic engagement with texts to help ESL students promote reading comprehension skills" (Grabe, 2004, p. 55).

Recently, in the EFL context, there have been a few studies on teaching reading strategies in English reading programs. More specifically, several studies investigated the effectiveness of explicit English reading strategy instruction on the positive improvement of Korean college students' reading ability of English texts (Kim, 2006; Lee, 2007; Park, 1996; Song, 1998). For example, Song (1998) taught college students reading strategies with newspaper articles in English. The students were trained to self-report on how they read the articles. The strategy training showed that the students enhanced their ability to understand readings in English, and their reading speed to find out what happened in the story became faster. Lee (2007) taught six reading strategies to college students and found that students' attitudes toward strategy training became more positive after practicing with familiar grammar-related activities. 


\section{Instructional Approaches}

According to Grabe (2004), in L1 reading research, 10 approaches-KWL (Know, Want to know, Learned), ETR (Experience-Text-Relate), QAR (Question-AnswerResponse), DR-TA (Directed Reading and Thinking Activities), Reciprocal Teaching, CSR (Collaborative Strategic Reading), Direct Explanation, Questioning the Author, TSI (Transactional Strategies Instruction), and CORI (Concept-Oriented Reading Instruction-are commonly taught as effective reading strategies. In this paper, among the ten reading instruction approaches, only four reading strategy approaches-ETR, RTA, TSI, and the CALLA-were reviewed for reading comprehension strategy instruction in ESL/EFL contexts. The first one is the ETR approach.

\section{Experience-Text-Relationship Approach}

According to Lawrence (2007), the ETR approach was originally associated with Kathrin $\mathrm{Au}$. Young Hawaiian children were instructed with the ETR approach and were found to comprehend better than those children who were not $(\mathrm{Au}, 1977)$. The ETR model aims to activate students' prior knowledge and experiences to enhance both reading motivation and comprehension. It has three basic ingredients: (1) experience, (2) text, and (3) relationship. The first step is the experience part. The teacher encourages students to discuss their experiences or background knowledge related to the story or topic of the study. By asking the learners discussion questions about the story, a motivating reading environment can be created. Next, the teacher tells the learners to read the text and asks them comprehension questions to check their understanding of the text. Finally, the teacher relates what learners discussed to their prior knowledge. Carrell, Pharis, and Liberto (1989) used this model to teach bilingual university students, and the results showed that the students trained in the ETR model improved their comprehension of TOEFL passages the most of all the groups tested. They were also able to make semantic maps with no scaffolding after being trained with this approach.

\section{Reciprocal Teaching Approach}

The RTA was originally proposed by Palinscar and Brown $(1984,1986)$ based on a cognitive-constructivist theory of reading. In the RTA, the reader is expected to use his or her prior knowledge to comprehend the text, under the assumption that reading is a meaning-making process. The role of the teacher within this model is to scaffold the students by modeling reading strategies including generating questions, clarifying text, summarizing and making predictions. More specifically, the teacher summarizes the passage first. Then the teacher generates questions about the passage. Next, the teacher predicts the following passage. Finally, the teacher clarifies the key points showing "critical evaluation of the passage in terms of consistency and compatibility with prior knowledge and common sense" (Song, 1998, p.45).

The teacher is primarily responsible for the initial instruction, but the responsibility is gradually transferred to the students. The students are often 
divided into groups, and each group discusses the text including summarizing, asking questions, clarifying misunderstandings, and generating predictions. Song (1998) investigated this model in an EFL context in Korea, and the results showed that the students who had the lowest comprehension scores initially improved the most after receiving instruction using this technique. Padron (1992) examined the effects of reciprocal teaching combined with the Question-Answer-Relationships approach in Hispanic bilingual elementary school students. Students instructed using the reciprocal teaching approach were shown to use more strategies, including summarizing and self-generated questions, which were positively related to reading achievement.

\section{Transactional Strategy Instruction}

According to Allen (2003), Michael Pressley is considered the designer of TSI. Similar to the RTA, the TSI model is based on a constructivist point of view. Teachers of TSI believe that "learners who construct their own knowledge of subject areas rather than being taught such knowledge have a greater ownership of the material" (Allen, 2003, p. 326). With this assumption, the TSI teacher usually starts his or her lesson by explaining strategies that will be used in the class. Then the teacher models the strategies by thinking aloud. After the teacher's modeling, students are encouraged to take turns practicing the strategies presented. If necessary, the teacher can intervene in peer group discussions and talk to students directly about their reading strategy problems while helping them construct an understanding of the strategies and the ways to use them. Following this procedure, students are able to acquire a deep, personal understanding of the strategies on their own.

Unlike studies of the RTA, research into the effectiveness of the TSI model tends to be long-term since the model is based on long-term instruction. Consequently, the studies are often in the form of ethnographies, ethnographic interviews, long-term case studies, and analyses of classroom discourse (Pressley \& Warton-McDonald, 1997). Both the RTA and the TSI model subscribe to a similar teaching protocol: (1) summarizing, (2) generating and answering questions, (3) making predictions, and (4) clarifying the unclear parts. People who use the TSI model try to find how questions, including how comprehension strategies are related to other subject areas and how students forge meaning out of potentially ambiguous text types (Allen, 2003).

Collin (1991) showed an improvement in standardized measures of comprehension after students were taught comprehension strategies in the TSI model. Notably, Brown, Pressley, Van Meter, and Schuder (1996) showed that the students who were taught in the TSI model interpreted the texts in a richer and more diverse way, understood more of the content of the lessons, and exhibited a higher retention rate for the material that they learned. 


\section{The Cognitive Academic Language Learning Approach}

CALLA was originally developed by Anna Chamot and Michael O'Malley in 1987 based upon cognitive learning (Lawrence, 2007). The CALLA model is designed to enable ESL students to develop their language skills within content area subjects while implementing effective strategies. In other words, it aims to promote ESL students' academic achievement while at the same time improving their language skills. Under the premise that learning is an active and dynamic process, the model assumes that (1) active learners are productive learners, (2) strategies can be learned, (3) academic content learning is more effective with strategy use, and (4) learning reading strategies can transfer to new learning (Lawrence, 2007). Like RTA and TSI, CALLA is based on constructivism and cognitive theory. Allen (2003) suggested that "learning new information requires mental processing through organizing the information, elaborating it, and linking it with existing knowledge" (p. 329).

According to Chamot and O'Malley (1997), the CALLA model consists of three components: (1) topics from the major content subjects, (2) the development of academic language skills, and (3) explicit instruction in learning strategies for both content and language acquisition. More specifically, this model incorporates actual topics that students will encounter in grade-level classrooms. The content areas should be introduced gradually so as not to overwhelm students with both language and content. Chamot and O'Malley (1997) suggested that "the first content subject introduced should either have extensive contextual supports for learning or reduced language demands" (p. 10).

CALLA is not only used for reading strategy instruction but also for development of all four language skills (that is, speaking, listening, reading and writing). The skills are taught using the academic subject matter with the purpose of developing academic language skills. In addition to this, students learn important concepts and skills such as analyzing, evaluating, justifying, and persuading by using academic language.

In terms of learning strategy instruction, teachers are expected to teach cognitive, social/affective, and metacognitive strategies. Chamot and O'Malley (1996) suggested that the strategies should be taught explicitly by the teacher; thus scaffolding is an important aspect of teaching strategies within this model. Allen (2003) claimed that "students develop effective learning behaviors by watching teachers and other experts as they perform learning tasks. Then by practicing these behaviors with support until they are able to do them alone, students can internalize them" (p. 330). To summarize, the CALLA model is based on cognitive theory and integrates academic language development, content area instruction, and explicit instruction in learning reading strategies.

The three components of the CALLA model are realized in a five-stage instructional sequence: (1) preparation, (2) presentation, (3) practice, (4) evaluation, and (5) expansion. First, the teacher poses questions to students in order to elicit their background knowledge and strategies in the preparation stage. 
Second, the teacher presents new strategies, concepts, and language through modeling in the presentation stage. The teacher is encouraged to use lots of visuals and demonstrations. Third, students use the strategies they learn from modeling and apply the strategies more effectively with new tasks in the practice stage. They verbalize and describe their efforts to apply strategies with learning activities, often working with classmates in a collaborative manner. In the fourth stage students raise their metacognitive awareness of what they achieved and assess their learning process. Finally, in the expansion stage, the students relate what they learned to their culture and transfer strategies they learn to the outside world. The following figure demonstrates each stage (Chamot \& Robbins, 2005, pp. 11-13):

- Identify objectives.

\section{Preparation}

- Elicit students' prior knowledge.

- Develop vocabulary.

- Provide motivation.

\section{Presentation}

- Present new information in varied ways.

- Model processes explicitly.

- Explain learning strategies.

- Discuss connections to students' prior knowledge.

\section{Practice}

- Use hands-on/inquiry-based activities.

- Provide different cooperative learning structures.

- Use authentic content tasks.

- Ask students to use learning strategies.

\section{Self-evaluation}

- Students reflect on their own learning.

- Students evaluate themselves.

- Students assess their own strategy use. 


\section{Expansion}

- Students apply information to their own lives.

- Students make connections between language and content.

- Students relate information to first language knowledge.

- Parents contribute to learning.

Figure 1. CALLA instructional sequence: Five recursive phases

The teacher's objectives in the CALLA model are to activate background knowledge, to explain and model the target strategies, to prompt use of strategies and give feedback, to assess students' strategies, and to support transfer and application of strategies. Corresponding to the teacher's aims, students participate in discussions, apply strategies with guidance, self-assess strategies, use strategies independently, and transfer strategies to new tasks.

A series of studies have been conducted using the CALLA model in the field of language-learning strategies for ESL/EFL students in academic settings (Chamot, 1993; Chamot \& O'Malley, 1987; O'Malley \& Chamot, 1990; Rasekh \& Ranjbary, 2003). For example, Chamot and O'Malley (1987) trained bilingual secondary students and showed that CALLA positively affected metacognitive strategy use. Rasekh and Ranjbary (2003) trained bilingual university students and showed that CALLA positively affected vocabulary scores. In short, the results of the studies have shown that student performance in content, language, and use of learning strategies tends to improve after receiving instruction using the CALLA method.

\section{Strategy-Based Reading Instruction in the CALLA Model}

Among the instructional models previously described, the CALLA instructional model was selected in this paper in order to illustrate strategy-based reading instruction. Since the CALLA instruction promotes both language and content development in explicit instruction of learning strategies, it is most appropriate to the lesson topic of this illustration: raising awareness of important AfricanAmerican figures in modern history. I chose this topic since negative stereotypes and prejudiced points of view regarding African-Americans still persist in the present day. By dealing with this topic in class, teachers are not only able to promote a balanced and tolerant mind set towards African-Americans but also able to bolster students' content knowledge and academic language skills. More specifically, this strategy-based lesson plan follows the CALLA instructional plan (see Appendix A). This lesson is on the topic of an important African-American woman, Oprah Winfrey. Prior to the delivery of this lesson plan, students will be asked to do some research about important African-American figures in history on their own. The lesson plan is designed for postsecondary students whose English reading proficiency levels are between intermediate and high-intermediate. 


\section{A Lesson Plan: Oprah Winfrey}

A. General Overview

- Time needed: 50 minutes

- Grade/Language Level: Intermediate English proficiency level

B. Standards

1) Content Objective

- Collaborating with their classmates, students will be able to read and understand a passage about Oprah Winfrey.

2) Strategy Objectives

- Students will be able to use the title of the textbook to predict what they will learn.

- Students will be able to guess the meaning of new words using context and their background knowledge.

- Students will be able to practice such reading strategies as skimming and summarizing.

3) Language Objectives

- Students will be able to practice listening, speaking, reading, and writing to improve their understanding of the story in English.

- Students will be able to participate in pair, group, and whole-class discussions to express their ideas in English.

C. Materials

1) Textbook story: “Beating the odds." In Wegmann, B., \& Knezevic, M. (2002), Mosaic 1 reading, $4^{\text {th }}$ ed. New York: McGraw-Hill.

2) Oprah Winfrey show. ([2005]). The Oprah Winfrey Show: 20th Anniversary Collection. Hollywood: Paramount Pictures.

3) Slide projector / Cassette tape / Cassette tape player

4) Inquiry chart (Appendix B)

5) Reference list of Oprah Winfrey (Appendix C)

6) Checklist for CALLA lesson objectives (Appendix D)

D. Procedures

1) Preparation

- Warm-up (5 minutes): The teacher will ask students whether they recognize Oprah Winfrey in a picture in their book. The teacher tells the students she is one of the richest female entertainers in the world and has fought against discrimination. The teacher asks the students to name other African-American heroes. The teacher draws a clustering graph on the board with the word "African-Americans" in the center of the graph and puts key words in the graph based on students' answers. The teacher briefly summarizes the history 
of African-Americans in the United States including discrimination, prejudice, segregation, and the Civil Rights movement in the 1960s and 1970s. The teacher asks students to think about what the title tells them about Oprah Winfrey's life. [Predicting + Graphic organizer + Brainstorming + Selfassessment of prior knowledge]

- Watching Oprah show (5 minutes): Students will watch a video clip of the Oprah show. After watching it, students will be asked what they feel and what they learn about her. The teacher tells the class that millions of domestic viewers in the United States watch the Oprah TV talk show each week. The teacher also informs them that Oprah has influence in other areas such as social awareness, publishing, film, philanthropy, and education. [Active listening for getting information of the topic]

2) Presentation (6 minutes)

- The teacher plays a tape of the passage and students listen to understand the text. Then the teacher models a reading of the first paragraph using the think-aloud technique in order to demonstrate how to predict vocabulary meanings, how to summarize, and how to skim the passage to get information. [Listening strategy for getting the main idea of the passage + Modeling in think-aloud technique]

3) Practice

- Contextualizing vocabulary (5 minutes): The teacher distributes a word list to students. The teacher asks students to answer questions on the words in the textbook. The teacher encourages them to use their intuition, knowledge of word structure, and inferences. The teacher goes over the answers in class. [Selecting the appropriate words for the given context]

- Jigsaw (15 minutes): The teacher organizes the class into groups of four, and each group focuses on two or three paragraphs. Each group summarizes each of their paragraphs in English and helps each other if there are unfamiliar sentence structures or words. The teacher helps students if there is a question. After the time is up, each group rotates so that new groups are formed to share what they discussed in their previous group in English. [Summarizing + Reciprocal teaching + Practicing speaking in the target language + Cooperating to complete tasks]

- Identifying positive and negative points (12 minutes): The teacher tells students that the article describes not only positive influences but also negative influences in the early life of Oprah Winfrey. The teacher asks students to work with a partner to make two lists: the people, places, and events that positively influenced Oprah and the people, places, and events that negatively influenced her. The teacher models first how to do this activity by showing an example. After the time is up, students compare their list with the lists of others. [Modeling + Scanning + Making a chart + Cooperating to complete tasks] 
4) Expansion: Homework and wrap-up (2 minutes)

- The teacher assigns students homework: vocabulary recall list from the textbook and Inquiry Chart (see Appendix B). The teacher models how to fill out the columns of the chart. For the following class, the teacher asks students to research recent events in Oprah's life by using reliable sources (see Appendix C).

5) Evaluation

- Students will assess their own learning by doing the vocabulary recall list and inquiry chart for homework. Students will also do peer-to-peer evaluation by sharing their ideas or opinions of their strategy use. The teacher assesses his or her lesson plan by checking the checklist for CALLA lesson objectives (see Appendix D). The teacher also assesses students' understanding of the lesson using the objectives as follows:

- Language objective: Do the students participate by expressing their feelings or opinions with regards to the teachers' questions? Do the students speak English as much as possible? Do the students help one another in pair and group activities? Do the students actively listen to the text and to others' opinions?

- Strategy objective: Do the students make educated guesses about the meaning of unfamiliar words? Do the students actively participate in listening, graph clustering, summarizing, and skimming? How helpful was watching the teacher complete the think-aloud demonstration in helping students figure out how to apply the reading strategies to their own work? Was using the chart useful in extracting and organizing information from the passage? What technique proved to be the most helpful in aiding students to comprehend the reading?

\section{Conclusion}

Despite the growing demand for quality reading instruction in the English as a Foreign/Second Language context and despite the mounting body of literature on first-language reading strategy use, there appears to be a sizable gap in research on effective reading strategies for EFL and ESL learners. Due to this lack of pertinent research, there has yet to appear an agreed-upon set of guidelines for teaching reading strategies in the EFL and ESL contexts. Therefore, the aim of this paper is to provide a model for how one might incorporate strategic reading instruction into classrooms. Among the four different strategy-based reading models, I described the CALLA model in detail since it is especially focused on promoting content knowledge and language skills. Using the CALLA teaching protocol as well as the sample lesson plan described in this paper, teachers will be able to implement strategies for reading instruction in their own classrooms. They will also be able to adjust or expand on the model and demonstration by adding their ideas and experiences while instructing reading strategies in their classrooms. 
One limitation of this paper is that the lesson plan presented here has not been implemented in a real EFL classroom. For this reason, it is necessary to conduct follow-up studies that utilize the CALLA model in a real setting. In doing so, it would be possible to see whether or not the lesson presented in this study is actually helpful in authentic EFL classes. Such research would also allow for a more in-depth assessment of teachers' feeling towards and experiences with teaching in this manner.

\section{References}

$\mathrm{Au}, \mathrm{K} . \mathrm{H}$. (1977). Cognitive training and reading achievement. Paper presented at the annual meeting of the Association for the Advancement of Behavior Therapy. Atlanta, GA.

Alfassi, M. (1998). Reading for meaning: The efficacy of reciprocal teaching in fostering reading comprehension in high school students in remedial reading classes. American Educational Research Journal, 35(2), 309-332.

Allen, S. (2003). An analytic comparison of three models of reading strategy instruction. IRAL, 41, 319-338.

Baker, L. (2002). Metacognition in comprehension instruction. In C. Block \& M. Pressley (Eds.), Comprehension instruction: Research-based best practices (pp. 77-95). New York: Guilford Press.

Brown, R. (2002). Straddling two worlds: Self-directed comprehension instruction for middle schoolers. In C. Block \& M. Pressley (Eds.), Comprehension instruction: Research-based best practices (pp. 337-350). New York: Guilford Press.

Brown, R., Pressley, M., Van Meter, P., \& Schuder, T. (1996). A quasi-experimental validation of transactional strategy instruction with low-achieving secondgrade readers. Journal of Educational Psychology, 88, 18-37.

Carrell, P. L., Pharis, B. G., \& Liberto, J. C. (1989). Metacognitive strategy training for ESL reading. TESOL Quarterly, 23, 647-678.

Chamot, A. U. (1993). Student responses to learning strategy instruction in the foreign language classroom. Foreign Language Annals, 26, 308-321.

Chamot, A., \& O'Malley, M. (1987). The cognitive academic language learning approach: A bridge to the mainstream. TESOL Quarterly, 21, 227-249.

Chamot, A., \& O'Malley, M. (1996). The cognitive academic language learning approach: A model for linguistically diverse classrooms. The Elementary School Journal, 96, 259-273.

Chamot, A., \& O'Malley, M. (1997). The CALLA handbook: Implementing the cognitive academic language learning approach. New York: Addison-Wesley. 
Chamot, A., \& Robbins, J. (2005). The CALLA model: Strategies for ELL student success. Paper presented at the workshop for region 10 New York City Board of Education. New York, NY.

Collin, C. (1991). Reading instruction that increases thinking abilities. Journal of Reading, 34, 510-516.

Dole, J. A., Duffy, G. G., \& Pearson, P. D. (1991). Moving from the old to the new: Research on reading comprehension instruction. Review of Educational Research, 61(2), 239-264.

Duke, N., \& Pearson, P. D. (2002). Effective practices for developing reading comprehension. In A. Farstrup \& S. Samuels (Eds.), What research has to say about reading instruction (3 ${ }^{\text {rd }}$ ed., pp. 205-242). Newark, DE: International Reading Association.

Grabe, W. (2004). Research on teaching reading. Annual Review of Applied Linguistics, 24, 44-69.

Kim, H-O. (2006). Changes in learner beliefs and strategy use through strategybased instruction. Foreign Languages Education, 13(4), 193-217.

Kusiak, M. (2001). The effect of metacognitive strategy training on reading comprehension and metacognitive knowledge. EUROSLA Yearbook, 1(1), 255274.

Lawrence, L. J. (2007). Cognitive and metacognitive reading strategies revisited: Implications for instruction. The Reading Matrix, 7(3), 55-71.

Lee, K. R. (2007). Self-confidence fostering activities: Scaffolds for EFL learners' reading strategies. English Language Teaching, 19(4), 27-50.

Nist, S. L., \& Diehl, W. (1990). Instructor's guide: Developing textbook thinking $\left(^{\text {nd }}\right.$ ed.). Lexington, MA: Heath.

O'Malley, J. M., \& Chamot, A. U. (1990). Learning strategies in second language acquisition. New York: Cambridge University Press.

Oprah Winfrey show. ([2005]). The Oprah Winfrey show: 20th anniversary collection. Hollywood, CA: Paramount Pictures.

Padron, Y. N. (1992). The effect of strategy instruction on bilingual students' cognitive strategy use in reading. Bilingual Research Journal, 16(3\&4), 35-51.

Palinscar, A., \& Brown, A. (1984). Reciprocal teaching of comprehension-fostering and comprehension monitoring activities. Cognition and Instruction, 1, 117175.

Palinscar, A., \& Brown, A. (1986). Interactive teaching to promote independent learning from text. The Reading Teacher, 39(8), 771-777. 
Park, Y. Y. (1996). Self-regulated strategy training in second language reading: Its effects on reading comprehension, strategy use, reading attitudes, and learning styles of university ESL students. Foreign Languages Education, 2(1), 59-80.

Pressley, M. (2002a). Comprehension strategy instruction: A turn-of-the-centurystatus report. In C. Block \& M. Pressley (Eds.), Comprehension instruction: Research-based best practices (pp. 11-27). New York: Guilford Press.

Pressley, M. (2002b). Metacognition and self-regulated instruction. In A. Farstrup \& S. Samuels (Eds.), What research has to say about reading instruction ( $3^{\text {rd }}$ ed., pp. 291-309). Newark, DE: International Reading Association.

Pressley, M., \& Warton-McDonald, R. (1997). Skilled comprehension and its development through instruction. School Psychology Review, 26(3), 448-466.

Rasekh, Z., \& Ranjbary, R. (2003). Metacognitive strategy training for vocabulary learning, TESL-EJ, 7(2), 1-18.

Song, M. J. (1998). Teaching reading strategies in an ongoing EFL university reading classroom. Asian Journal of English Language Teaching, 8, 41-54.

Trabasso, T., \& Bouchard, E. (2002). Teaching readers how to comprehend text strategically. In C. Collins \& M. Pressley (Eds.), Comprehension instruction: Research-based best practices (pp. 176-200). New York: Guilford Press.

Wegmann, B., \& Knezevic, M. (2002). Mosaic 1 reading (4th ed.). New York: McGrawHill.

Vaughn, S., \& Klingner, J. K. (1999). Teaching reading comprehension through collaborative strategic reading. Intervention in School and Clinic, 34(5), 284292.

\section{Appendix A. The CALLA Handbook, Table 5.3}

\section{CALLA Instructional Plan}

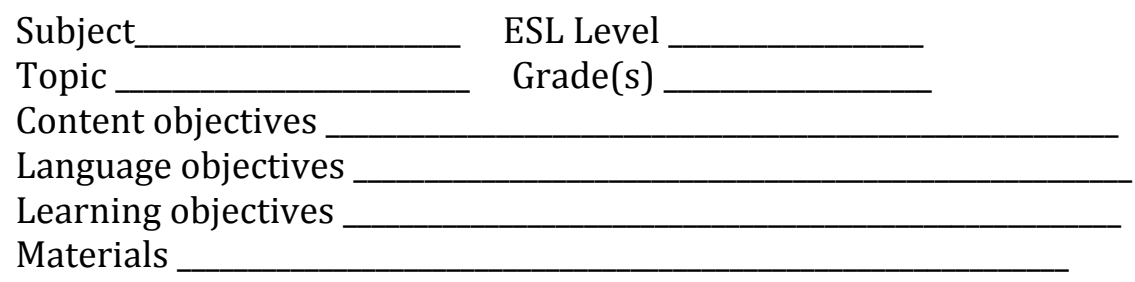

\section{Procedures}

1. Preparation: How will you find out what your students already know about the topic?

2. Presentation: How will you present and explain the topic?

3. Practice: What cooperative learning activities will provide meaningful practice?

4. Evaluation: How will students assess their own learning?

5. Expansion: What thinking-skills discussion questions are appropriate? How will students apply what they have learned in the unit to new situations? 


\section{Appendix B. Inquiry Chart}

\begin{tabular}{|l|l|l|}
\hline What do you KNOW? & What do you WANT to find out? & What did you LEARN? \\
$\begin{array}{lll}\text { - Oprah is an African- } \\
\text { American. }\end{array}$ & $\begin{array}{l}\text { - The civil war } \\
\text { - The civil rights era }\end{array}$ & - She was a very smart girl. \\
\hline
\end{tabular}

\section{Appendix C. Useful Resources of Oprah Winfrey}

[Books]

Cooper, I. (2007). Oprah Winfrey. New York: Penguin Group.

Holland, G. (2001). Oprah Winfrey. Chicago: Heinemann Library.

Mara, W. (2005). Oprah Winfrey. New York: Children's Press.

Corliss, R. (1998). Bewitching Beloved. Time. [New York : Time Inc.].

[DVDs]

Spielberg, Stephen (Director). The Color purple. (1997 [1985]). Burbank, CA: Warner Home Video.

Demme, Jonathan (Director). Beloved. (1999). Hollywood, CA: Touchstone Home Video.

Oprah Winfrey show. (2005). The Oprah Winfrey show: 20th anniversary collection.

Hollywood, CA: Paramount Pictures.

[WWW Resources]

http://www.gale.com/free resources/bhm/bio/winfrey o.htm

http://www.oprah.com/about/press/about press bio.jhtml

http://en.wikipedia.org/wiki/Oprah Winfrey

\section{Appendix D. The CALLA Handbook, Table 7.7}

\section{Checklist for CALLA Lesson Objectives}

1. Objectives stated for content, language, and learning strategies

2. Content selected is essential for grade level(s) and is aligned with state framework/local curriculum

3. Activities are included that develop vocabulary, listening, reading, speaking, and writing

4. One or two learning strategies directly taught and/or practiced

5. Language somewhat simplified, but not tightly controlled for grammatical structures or vocabulary

6. Students' prior knowledge elicited in Preparation phase

7. Context provided through visuals, graphic organizers, manipulatives, realia, hands-on, etc.

8. Cooperative learning activity and active practice with new information presented included in lesson

9. Self-evaluation activity included in lesson

10. Higher-level questions posed during lesson

11. Real-life applications of content addressed through activity and/or discussion 